ROCZNIKI KULTUROZNAWCZE

Tom/Vol. XII, numer/number 1 - 2021

DOI: http://doi.org/10.18290/rkult21121-11

RAPHAEL SASSOWER

\title{
EXPOSURE AND DISCLOSURE OF ARTWORKS
}

In an age when post-truth is considered an excuse for disavowing the difficult search for truth and replacing it with cynicism toward opponents' views, contemporary controversies related to the art world in the United States offer glimpses of the importance of critical intervention and laying bare hypocritical conduct. Three recent cases are worth briefly mentioning here, cases in which racial capitalism and philathrocapitalism are made to reckon if not to atone for continuing business as usual.

The first case relates to the legal action brought on March 20, 2019 by Tamara Lanier against Harvard University for the possession and display of daguerreotypes of her ancestors, Renty and Delia, who never consented to nor received compensation for posing naked for Louis Agassiz in 1850 (Courthousenews.com 2019). In addition to the grotesque reminder of the abuses of so-called objective and value-neutral scientific research, especially when studying slaves, some scholars have understood this case as representative of the imperialist power and agency of photography itself. Despite traditional praise for photography as an art form that is both transparent and embodies democratizing powers, critiques of the technology and its practice have insisted on the exploitive dimension of encapsulating the images of subjugated and powerless people without their consent or the historical context of the "capture" of their images (e.g., Azoulay 2019). Post-colonial studies of the complicity of artists and their crafts in imposing standards not only of beauty but also of humanity have proliferated recently, adding conceptual rethinking to earlier work on the plunder of artistic objects from around the world and their celebratory display in "civilized" Western muse-

Prof. RAPHAEL SASSOWER — University of Colorado, USA; e-mail: rsassowe@uccs.edu; ORCID: https://orcid.org/0000-0003-3501-6013. 
ums. Would unconditional reparation and return of stolen art objects mend the wounds of settler-colonial violence and systematic extraction?

The second case relates to the controversy over what to do with over seventeen hundred confederate memorials (Southern Poverty Law Center 2018; over seven hundreds of which are monuments and statutes), which are painful reminders of Black enslavement and the continued systemic racist discrimination against Blacks in America by white supremacists and others complicit in their actions. Some have argued for leaving these statues in place and adding plaques that describe the horrors and injustice of slavery (e.g., Forest and Johnson 2018). Others have suggested removing them from urban centers (with or without replacement plaques) and displaying them, either in museum spaces dedicated to America's shameful history or in cemeteries and battlefields (e.g., Mitchell 2020). More recently, some artists have offered to overlay these statues with, for example, a hologram of George Floyd who was murdered by the police in Minnesota on May 25, 2020 (Schwartz 2020). America's reckoning with its history and ongoing racism is finally publicly debated, using the legal status and future of confederate statutes as a focal point of reference (e.g., Owley and Phelps 2018). Would the removal of statues and monuments to the Confederacy have the power to rewrite American history and erase ongoing racism in America?

The third case relates to Warren Kanders who was forced to resign from the Whitney Museum's board in 2019 in response to artists boycotting the Whitney Biennial and protests from other board members. Kanders is the CEO and majority owner of a company that produces tear gas used to disperse peaceful protesters, among many other businesses he owns. At issue is an age-old debate over the inescapable patronage of art and its ramifications, from the complicity of artists to the inevitable ideological influence of commissioning and funding artworks (BOGART 1995). In this case, philanthropy is the method by which capitalist dominance over contemporary culture is cleverly exercised. It simultaneously attempts to wash clean the dirty hands of donors, purchase social status and legitimacy, control the art market by funding purchases of artworks they already own in their private collections (thereby increasing their value), and influence the aesthetic tastes of others (e.g., Davis and Halperin 2019). Is it possible for the art world in capitalist societies to survive, let alone flourish, without wealthy patrons (given the state's reluctance to support artists and art venues)?

Though different in so many ways, these three cases illustrate the inescapable politicization of the art world and the suffusion of capitalist logic beyond 
the economy and into the art world. The pretense that it is possible to insulate art and artists from their economic-political setting is hubris. In its stead, critical engagement will place artists and their work at the front lines of old and new battles over integrity and humanity, posing larger cultural and political questions to intellectuals and politicians alike.

\section{BIBLIOGRAPHY}

Azoulay, Ariella Aisha. 2019. Potential History: Unlearning Imperialism. London and New York: Verso.

Bogart, Michele. 1995. Artists, Advertising, and the Borders of Art. Chicago and London: University of Chicago Press.

Courthouse news.com March 20, 2020. Accessed December 11, 2020. https://www.courthouse news.com/wp-content/uploads/2019/03/harvard-photos.pdf.

Davis, Ben, and Julia HALPERIN. 2019. "Warren Kanders Resigns from the Whitney's Museum's Board, Following Months of Protest and a Renewed Artists Boycott." artnet.news, July 25, 2019. Accessed August 11, 2020. https://news.artnet.com/art-world/kanders-resigns1609330.

Forest, Benjamin, and Juliet Johnson. 2018. "Confederate monuments and the problem of forgetting." Cultural Geographies. Accessed September 11, 2020. https://journals.sagepub. com/doi/10.1177/1474474018796653.

Mitchell, Mary Niall. 2020. "We always knew it was possible: The long fight against symbols of white supremacy in New Orleans." City: Analysis of Urban Change, Theory, Action 24, issues 3-4. Accessed August 11, 2020.https://www.tandfonline.com/doi/full/10.1080/ 13604813.2020. 1784580.

Owley, Jessica, and Jess Phelps. 2018. "Understanding the Complicated Landscape of Civil War Monuments." Indiana Law Journal 93, issue 5. Accessed September 11, 2020. https:// www.repository.law.indiana.edu/ cgi/viewcontent.cgi?article $=11322 \&$ context $=i l j$.

SchwartZ, Rafi. 2020. "A new art project will project a hologram of George Floyd over Confederate monuments," Mic. (July 29, 2020). Accessed September 11, 2020. https://www. $\mathrm{mic} . \mathrm{com} / \mathrm{p} / \mathrm{a}$-new-art-project-will-project-a-hologram-of-george-floyd-over-confederatemonuments-30233827.

\section{EXPOSURE AND DISCLOSURE OF ARTWORKS}

\section{S u m m a ry}

The artworld's ongoing imbrication in and complicity with the ever-growing web of hypercapitalism is evident in the United States. Any pretense to the contrary exposes hypocritical conduct on the fronts of artistic production, distribution, and consumption. Only public engagement with and support of the art community writ large can offer potential protection against the unwarranted and unwanted financial and political intrusion.

Keywords: philanthropy; capitalist appropriation; aesthetic racism; public art; funding. 


\section{EKSPOZYCJA I UJAWNIENIE DZIEŁA SZTUKI}

\section{Streszczenie}

W Stanach Zjednoczonych widoczne jest ciągłe uwikłanie i współudział świata artystycznego w stale rozrastającej się sieci hiperkapitalizmu. Jakiekolwiek udawanie, że jest inaczej, obnaża hipokryzję na frontach produkcji, dystrybucji i konsumpcji sztuki. Jedynie publiczne zaangażowanie i wsparcie społeczności artystycznej jako takiej może zaoferować potencjalną ochronę przed nieuzasadnioną i niechcianą ingerencją finansową i polityczną.

Słowa kluczowe: filantropia; zawłaszczenie kapitalistyczne; rasizm estetyczny; sztuka publiczna; finansowanie. 